\title{
KOMUNITAS IKAN PADA EKOSISTEM PADANG LAMUN DAN TERUMBU KARANG DI PULAU SIBU KECAMATAN OBA UTARA KOTA TIDORE KEPULAUAN
}

\author{
Rina ${ }^{1}$, Salim Abubakar ${ }^{1}$, Nebuchadnezzar Akbar $^{2}$ \\ ${ }^{1}$ Program Manajamen Sumberdaya Perairan, FPIK. Universitas Khairun \\ Ternate \\ ${ }^{2}$ Program IImu Kelautan, FPIK. Universitas Khairun Ternate \\ E-mail : salimbbkr@gmail.com
}

\begin{abstract}
ABSTRAK
Penelitian bertujuan untuk melihat komposisi jenis dan indeks ekologi ikan pada ekosistem lamun dan terumbu karang di Pulau Sibu Kecamatan Oba Utara. Proses penangkapan ikan baik pada ekosistem padang lamun maupun terumbu karang menggunakan jaring insang dengan panjang 50 meter dan lebar 2 meter dan ukuran mesh size 2,5 inchi. Komposisi jenis hasil tangkapan pada ekosistem terumbu karang sebanyak 16 spesies yaitu Tylosurus crocodiles, Cheilio inermis, Gerres oyena, Choerodon robustus, Parupeneus berbirinus, Sillago sihama, Hermigymnus melapterus, Lethrinus erythropterus, Lutjanus decussates, Lutjanus fulvilamma, Lutjanus bengalensis, Siganus canaliculatus, Siganus chrysospilos, Caranx melampygus, Selar boops dan Cephalopholis microprion. Sedangkan pada ekosistem padang lamun sebanyak 13 spesies yaitu Myripristis burndti, Tylosorus strongylurus, Caranx melampygus, Siganus canaliculatus, Siganus chrysospilos, Sillago sihama, Lutjanus ehrenbergii, Lutjanus decussates, Lutjanus fulvilamma, Monotaxis granduculis, Parachaetodon ocellatus, Hermigymnus melapterus dan Sphyraena jello. Keanekaragaman jenis ikan baik pada ekosistem terumbu karang maupun padang lamun tergolong sedang, tidak ada jenis yang mendominasi serta penyebaran jenisnya sangat merata. Hasil tangkapan jenis ikan antara ekosistem terumbu karang dan padang lamun memiliki kemiripan.
\end{abstract}

Kata Kunci : Ikan, Lamun, Terumbu Karang

\section{ABSTRACT}

The research aim is ecology index and specieses composition in seagrass and corrals ecosystem in Sibu Island. Fishing proccess used gill net long 50, 2 meters and 2,5 inchi mesh size. The result fishing in corrals ecosystem was 16 specieses Tylosurus crocodiles, Cheilio inermis, Gerres oyena, Choerodon robustus, Parupeneus berbirinus, Sillago sihama, Hermigymnus melapterus, Lethrinus erythropterus, Lutjanus decussates, Lutjanus fulvilamma, Lutjanus bengalensis, Siganus canaliculatus, 
Siganus chrysospilos, Caranx melampygus, Selar boops dan Cephalopholis microprion. The seagrass ecosystems founded 13 specieses was Myripristis burndti, Tylosorus strongylurus, Caranx melampygus, Siganus canaliculatus, Siganus chrysospilos, Sillago sihama, Lutjanus ehrenbergii, Lutjanus decussates, Lutjanus fulvilamma, Monotaxis granduculis, Parachaetodon ocellatus, Hermigymnus melapterus dan Sphyraena jello. The fish diversity in seagrass and corrals ecosystem was medium category, specieses domination and distribution founded normal conditions. The the result catched obtainable similarity fish between seagrass and corrals ecosystems.

Keywords : Fish, Seagrass, Coral Reefs

\section{PENDAHULUAN}

Keanekaragaman hayati pesisir dan lautan hadir dalam bentuk ekosistem terumbu karang, mangrove, padang lamun, estuary, pantai terbuka, dan laut dalam. Hutan mangrove, padang lamun dan terumbu karang adalah ekosistem khas di daerah tropis dengan produktifitas dan keanekaragaman yang tinggi (Dahuri, 2003). Bengen (2003) menyatakan bahwa mangrove, terumbu karang dan padang lamun (seagrass) merupakan tiga ekosistem penting di pesisir. ketiganya saling berinteraksi dan membentuk suatu kesatuan ekosistem yang erat. Interaksi tersebut dapat berupa fisik, biologi maupun kimia. Lebih lanjut dikatakan bahwa secara biologi, terjadi interaksi antara ketiga habitat tersebut dalam menyediakan ruang dan media hidup bagi organisme laut. Organisme laut dalam berbagai tingkatan hidupnya bermigrasi dari dan ke masing-masing habitat, tipe migrasinya dapat dikelompokkan antara lain (1) migrasi sementara untuk mencari makan dan (2) migrasi tahapan hidup (larvae, post larva, juvenile, dewasa).

Kelimpahan ikan di daerah padang lamun biasanya lebih tinggi dibandingkan dengan daerah yang tidak bervegetasi seperti pasir, hancuran karang dan lumpur. Hal ini disebabkan karena padang lamun memiliki peranan secara ekologis dalam siklus hidup ikan, karena daerah ini dimanfaatkan oleh ikan sebagai habitat, daerah asuhan, daerah untuk berlindung dari predator, daerah pemijahan dan mencari makan (Abubakar dan Ahmad, 2013). Kelimpahan ikan yang hidup di daerah padang lamun dari hasil penelitian di beberapa daerah Maluku Utara seperti laporan Arief (2007) di perairan Pulau Maitara Kecamatan Tidore Utara, memiliki kelimpahan ikan sebanyak 5 famili, 5 genus dan 6 spesies. Selanjutnya Suhud (2009) dari hasil penelitian melaporkan bahwa di Pulau Sali Kecamatan Gane Barat memiliki kelimpahan ikan sebanyak 10 famili, 2 ordo, 10, genus dan 16 jenis, dengan jumlah individu terbanyak pada saat operasi penangkapan waktu malam hari saat terjadinya pasang. Hasil tangkapannya ada beberapa ikan karang yang memanfaatkan padang lamun untuk mencari makan. 
Jenis ikan karang dapat dibagi dalam tiga kelompok yaitu kelompok jenis indikator (Famili Chaetodontidae), kelompok ikan target (Famili Lutjanidae, Siganidae, Acanthururidae, Mullidae, Scolopsidae) dan kelompok ikan yang berperan dalam rantai makanan (sebagian besar Famili Pomacantridae) (Adrim, 1993. Hasil penelitian Lumaela (2011) di Pulau Donrotu menemukan komposisi jenis ikan terumbu karang sebanyak 2 ordo (Perciformes, Tetraodontiformes), 8 famili (Siganidae, Scaridae, Monodactylidae Symphysanodontidae, Mullidae, Lutjanidae, Chaetodontidae dan Balistida.

\section{MATERI DAN METODE}

\section{Waktu dan Tempat Penelitian}

Penelitian akan dilaksanakan di Pulau Sibu Kecamatan Oba Utara Jota Tidore Kepulauan, Sedangkan waktu pelaksanaannya pada bulan 5 bulan yaitu Juli - Nopember 2017. Peta lokasi penelitian dapat dilihat pada gambar 1.

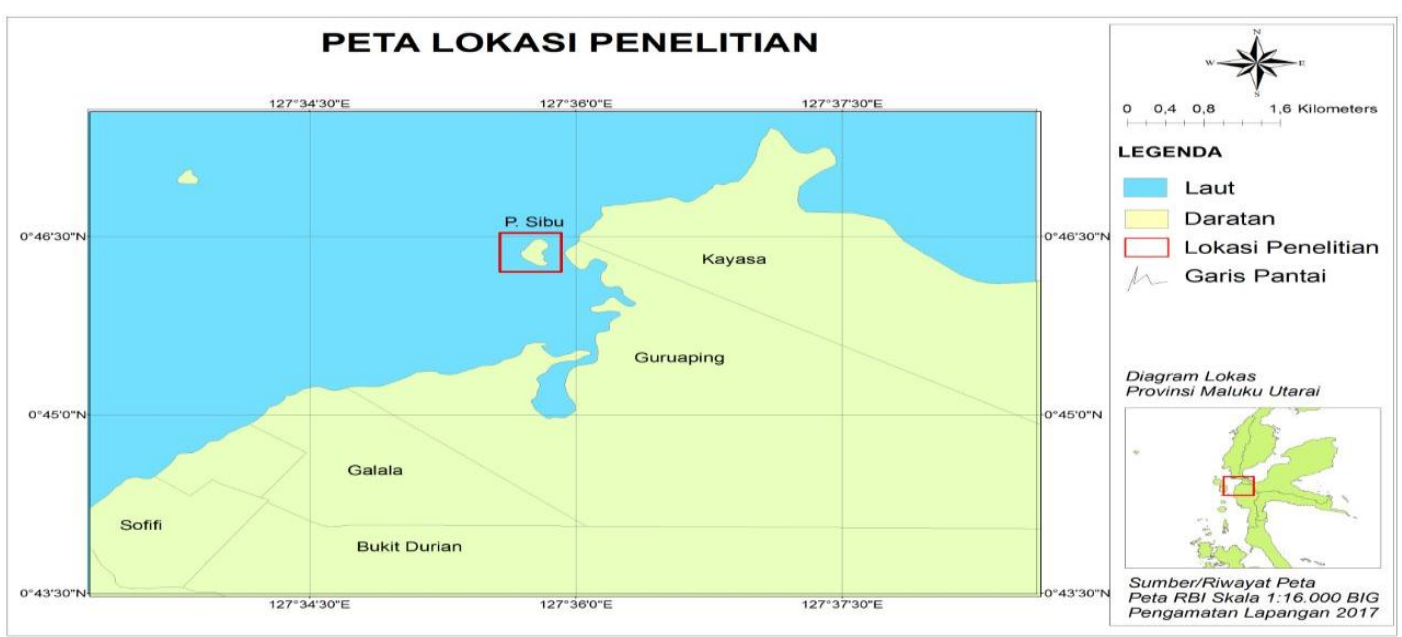

Gambar 1. Peta Lokasi Penelitian

\section{Metode Pengambilan Data}

Pengumpulan data dengan menggunakan metode ekperimental yaitu menggunakan jaring insang untuk membandingkan rata-rata hasil tangkapan ikan antara ekosistem padang lamun dan terumbu karang. Proses penangkapan ikan baik pada ekosistem padang lamun maupun terumbu karang menggunakan jaring insang dengan panjang 50 meter dan lebar 2 meter dan ukuran mesh size 2,5 inchi. Sebelum dilakukan penangkapan, jaring terlebih dahulu di atur agar tidak mudah terbelit. Pengoperasian jaring dilakukan pada areal padang lamun dan terumbu karang dengan arah melintang atau sejajar garis pantai. 
Jaring dioperasikan pada waktu siang pada saat air bergerak pasang. Lama perendaman alat tergantung air bergerak pasang sampai air bergerak surut, artinya setting dilakukan pada saat air bergerak pasang dan haulingnya pada saat air bergerak surut. Penangkapan dilakukan sebanyak 8 kali ulangan artinya satu kali ulangan sama dengan satu trip penangkapan. Proses penangkapan dengan bantuan perahu dan tenaga dari beberapa orang.. Hasil tangkapan yang diperoleh dimasukan ke dalam Cool box yang telah diberi es batu dan dibawa ke daratan untuk dideterminasi berdasarkan petunjuk Peristiwady (2006) dengan melihat ciri-ciri morfologi seperti warna tubuh, bentuk tubuh dan bentuk sirip. Ikan hasil determinasi selanjutnya dihitung jumlahnya serta dipisahkan berdasarkan famili, genus dan spesies

\section{Metode Analisis Data}

\section{Keanekaragaman Jenis}

Indeks keanekaragaman spesies menurut Shannon-Weaner dalam Rondo (2004) adalah :

$$
H^{\prime}=-\sum\left(\frac{n i}{N}\right) \operatorname{Ln}\left(\frac{n i}{N}\right)
$$

Dimana :

$\mathrm{H}^{*} \quad=$ Indeks keanekaragman spesies

$\mathrm{Ni} \quad=$ Jumlah individu dalam spesies ke-i

$\mathrm{N}=$ Jumlah total individu

\section{Indeks Dominansi Spesies}

Indeks dominansi mengikuti formula Rondo (2004)adalah :

$$
C=\sum\left(\frac{n i}{N}\right)^{2}
$$

Dimana :

$\mathrm{Ni}=$ Jumlah individu setiap spesies

$\mathrm{N} \quad$ = Jumlah total individu seluruh spesie

\section{Kemerataan Jenis (E)}

Kemerataan jenis digunakan untuk melihat penyebaran setiap organisme pada suatu habitat yang ditempati. Kemerataan jenis mengikuti formula (Wibisono, 2005) sebagai berikut : 


$$
E=\frac{H^{\prime}}{H_{\max }}
$$

Keterangan :

$\mathrm{E} \quad=$ Indeks kemerataan

$\mathrm{H}^{\prime} \quad=$ Keanekaragaman jenis

$\mathrm{H}_{\max }=\mathrm{Ln} \mathrm{S}$

$\mathrm{S} \quad=$ Jumlah taksa

\section{Perbedaan Hasil Tangkapan Ikan Padang Lamun dan Terumbu Karang}

Untuk mengetahui perbandingan hasil tangakapan ikan yang menghuni padang lamun dan terumbu karang yaitu dengan manganalisis jumlah individu yang diperoleh setiap trip penangkapan. Analisis perbandingan hasil tangkapan ikan yang menghuni padang lamun dan terumbu karang meliputi :

a. Uji Kenormalan Data Liliefors (Lolombulan, 2004) yaitu

Hipotesis statistik yang hendak di uji adalah :

$\mathrm{H}_{0}=$ Data menyebar normal (data distribusi normal).

$\mathrm{H}_{1}=$ Data tidak menyebar normal (data tidak berdistribusi normal)

Kriteria pengambilan keputusan :

$\mathrm{H}_{0}$ ditolak apabila $\mathrm{L}_{0}>\mathrm{L}$

$\mathrm{H}_{0}$ diterima apabila $\mathrm{L}_{0}<\mathrm{L}$

Apabila hipotesis $\mathrm{H}_{1}$ ditolak maka data dikonversi ke transformasi logaritma.

b. Perbedaan Hasil Tangkapan Ikan Padang Lamun dan Terumbu Karang

Pengujian hipotesis beda dua rata-rata (padang lamun dan terumbu karang), uji statistiknya distribusi $t$ (Hasan, 2002; Lolombulan, 2004)yaitu :

$$
t=\frac{\overline{X_{1}}-\bar{X}_{2}}{s \sqrt{\frac{1}{n_{1}}+\frac{1}{n_{2}}}}
$$

\section{HASIL DAN PEMBAHASAN}

\section{Komposisi Jenis Hasil Tangkapan}

Hasil tangkapan ikan menggunakan alat tangkap jaring insang selama 8 kali trip penangkapan diperoleh jumlah jenis hasil tangkapan pada ekosistem terumbu karang lebih tinggi dari pada ekosistem padang lamun. (Tabel 1) 
Tabel 1. Komposisi Jenis Hasil Tangkapan Ikan pada Ekosistem Terumbu Karang

\begin{tabular}{|c|c|c|c|c|}
\hline No & Ordo & Famili & Spesies & Nama Lokal \\
\hline 1 & Beloniformes & Belonidae & $\begin{array}{l}\text { Tylosurus } \\
\text { crocodiles }\end{array}$ & Sako \\
\hline 2 & Perciformes & Labridae & Cheilio inermis & Fee-fee \\
\hline 3 & Perciformes & Gerreidae & Gerres oyena & Kapas-kapas \\
\hline 4 & Perciformes & Serranidae & $\begin{array}{l}\text { Choerodon } \\
\text { robustus }\end{array}$ & Nuri -nuri \\
\hline 5 & Perciformes & Mullidae & $\begin{array}{l}\text { Parupeneus } \\
\text { berbirinus }\end{array}$ & Biji nangka \\
\hline 6 & Perciformes & Sillaginidae & Sillago sihama & Suo \\
\hline 7 & Perciformes & Pomacentridae & $\begin{array}{l}\text { Hermigymnus } \\
\text { melapterus }\end{array}$ & Mula \\
\hline 8 & Perciformes & Lethrinidae & $\begin{array}{l}\text { Lethrinus } \\
\text { erythropterus }\end{array}$ & Dusu \\
\hline 9 & Perciformes & Lutjanidae & $\begin{array}{l}\text { Lutjanus } \\
\text { decussates }\end{array}$ & Bangarau \\
\hline 10 & Perciformes & Lutjanidae & $\begin{array}{l}\text { Lutjanus } \\
\text { fulvilamma }\end{array}$ & Gorara \\
\hline 11 & Perciformes & Lutjanidae & $\begin{array}{l}\text { Lutjanus } \\
\text { bengalensis }\end{array}$ & Gorara \\
\hline 12 & Perciformes & Siganidae & $\begin{array}{l}\text { Siganus } \\
\text { canaliculatus }\end{array}$ & Uhi \\
\hline 13 & Perciformes & Siganidae & $\begin{array}{l}\text { Siganus } \\
\text { chrysospilos }\end{array}$ & Samandar \\
\hline 14 & Perciformes & Carangidae & $\begin{array}{l}\text { Caranx } \\
\text { melampygus }\end{array}$ & Puka putih \\
\hline 15 & Perciformes & Carangidae & Selar boops & Maar \\
\hline 16 & Perciformes & Serraniidae & $\begin{array}{l}\text { Cephalopholis } \\
\text { microprion }\end{array}$ & Geropa \\
\hline Jumlah & 4 ordo & 12 famili & 16 spesies & \\
\hline
\end{tabular}

Hasil tangkapan pada ekosistem terumbu karang terdiri dari 4 ordo, 12 famili dan 16 spesies yaitu Tylosurus crocodiles, Cheilio inermis, Gerres oyena, Choerodon robustus, Parupeneus berbirinus, Sillago sihama, Hermigymnus melapterus, Lethrinus erythropterus, Lutjanus decussates, Lutjanus fulvilamma, Lutjanus bengalensis, Siganus canaliculatus, Siganus chrysospilos, Caranx melampygus, Selar boops dan Cephalopholis microprion (Tabel 1).

Hasil tangkapan ikan pada ekosistem padang lamun terdiri dari 4 ordo, 10 famili dan 13 spesies yaitu Myripristis burndti, Tylosorus strongylurus, Caranx melampygus, Siganus canaliculatus, Siganus chrysospilos, Sillago sihama, Lutjanus ehrenbergii, Lutjanus decussates, 202 
Lutjanus fulvilamma, Monotaxis granduculis, Parachaetodon ocellatus, Hermigymnus melapterus dan Sphyraena jello (Tabel 2).

Tabel 2. Komposisi Jenis Hasil Tangkapan Ikan pada Ekosistem Padang Lamun

\begin{tabular}{|c|c|c|c|c|}
\hline No & Ordo & Famili & Spesies & $\begin{array}{l}\text { Nama } \\
\text { Lokal }\end{array}$ \\
\hline 1 & Beryciformes & Holocentridae & $\begin{array}{l}\text { Myripristis } \\
\text { burndti }\end{array}$ & Mamahe \\
\hline 2 & Gasterosteiformes & Belonidae & $\begin{array}{l}\text { Tylosurus } \\
\text { strongylurus }\end{array}$ & Sako \\
\hline 3 & Perciformes & Carangidae & $\begin{array}{l}\text { Caranx } \\
\text { melampygus }\end{array}$ & $\begin{array}{l}\text { Puka } \\
\text { putih }\end{array}$ \\
\hline 4 & Perciformes & Siganidae & $\begin{array}{l}\text { Siganus } \\
\text { canaliculatus }\end{array}$ & Uhi \\
\hline 5 & Perciformes & Siganidae & $\begin{array}{l}\text { Siganus } \\
\text { chrysospilos }\end{array}$ & Samandar \\
\hline 6 & Perciformes & Sillaginidae & Sillago sihama & Suo \\
\hline 7 & Perciformes & Lutjanidae & $\begin{array}{l}\text { Lutjanus } \\
\text { ehrenbergii }\end{array}$ & Gorara \\
\hline 8 & Perciformes & Lutjanidae & $\begin{array}{l}\text { Lutjanus } \\
\text { decussates }\end{array}$ & Bangarau \\
\hline 9 & Perciformes & Lutjanidae & $\begin{array}{l}\text { Lutjanus } \\
\text { fulvilamma }\end{array}$ & Gorara \\
\hline 10 & Perciformes & Lethrinidae & $\begin{array}{l}\text { Monotaxis } \\
\text { granduculis }\end{array}$ & Gofo \\
\hline 11 & Perciformes & Toxotidae & $\begin{array}{l}\text { Parachaetodon } \\
\text { ocellatus }\end{array}$ & Tetapeh \\
\hline 12 & Perciformes & Pomacentridae & $\begin{array}{l}\text { Hermigymnus } \\
\text { melapterus }\end{array}$ & Mula \\
\hline 13 & $\begin{array}{l}\text { Pickhandle } \\
\text { Barracuda }\end{array}$ & Sphyraenidea & $\begin{array}{l}\text { Sphyraena } \\
\text { jello }\end{array}$ & Paparok \\
\hline Jumlah & 4 Ordo & 10 Famili & 13 spesies & \\
\hline
\end{tabular}

Berdasarkan komposisi jenis ikan yang tertangkap pada kedua ekosistem umumnya merupakan ikan yang hidup di terumbu karang. Selain itu, hasil tangkapan yang diperoleh dari kedua ekosistem menunjukkan bahwa ekosistem terumbu karang memiliki jumlah tangkapan yang lebih banyak dibandingkan dengan padang lamun. Tingginya komposisi jenis ikan pada eksosistem terumbu karang, dikarenakan terumbu karang sebagai ruang, sumber pakan dan sebagai tempat atau habitat bagi berbagai jenis ikan karang. Jones (1991) dalam Norau (2010) menyatakan bahwa keberadaan lubang atau celah merupakan tempat perlindungan ikan karang, terutama selama adanya serangan badai atau serangan predator. Peningkatan jumlah tempat 
perlindungan mengakibatkan peningkatan kelimpahan ikan yang secara spesifik menjadikan karang sebagai tempat persembunyiaan. Lebih lanjut dikatakan Barnes (1980) dalam Norau (2010), bahwa salah satu sumber pakan bagi ikan karang yang banyak dijumpai di terumbu karang adalah lendir yang dihasilkan oleh karang yang sebenarnya digunakan karang untuk menangkap mangsanya. Lendir ini merupakan sumber pakan penting bagi jenis ikan tertentu dan hewan karang lainnya.

Komposisi jenis ikan yang tertangkap pada ekosistem padang lamun dari 13 jenis, terdapat 7 jenis ikan terumbu karang yaitu Myripristis burndti, Lutjanus ehrenbergii, Lutjanus decussates, Lutjanus fulvilamma, Monotaxis granduculis, Parachaetodon ocellatus dan Hermigymnus melapterus. Sedangkan dari 16 jenis ikan yang tertangkap pada ekosistem terumbu karang, terdapat 9 jenis ikan yang hidup di daerah padang lamun maupun pantai yaitu Tylosurus crocodiles, Cheilio inermis, Gerres oyena, Parupeneus berbirinus, Sillago sihama, Siganus canaliculatus, Siganus chrysospilos, Caranx melampygus dan Selar boops. Ini menunjukkan bahwa kedia ekosistem tersebut saling berinteraksi yaitu berupa interaksi biologi dalam menyedia habitat untuk mencari makan dimana ikan yang hidup di ekositem terumbu karang dapat bermigrasi mencari makan pada ekosistem padang lamun dan sebaliknya.

Bengen (2003) menyatakan bahwa mangrove, terumbu karang dan padang lamun (sea grass) merupakan tiga ekosistem penting di pesisir. ketiganya saling berinteraksi dan membentuk suatu kesatuan ekosistem yang erat. Interaksi tersebut dapat berupa fisik, biologi maupun kimia. Lebih lanjut dikatakan bahwa secara biologi, terjadi interaksi antara ketiga habitat tersebut dalam menyediakan ruang dan media hidup bagi organisme laut. Organisme laut dalam berbagai tingkatan hidupnya bermigrasi dari dan ke masing-masing habitat, tipe migrasinya dapat dikelompokkan antara lain (1) migrasi sementara untuk mencari makan dan (2) migrasi tahapan hidup (larvae, post larva, juvenile, dewasa).

\section{Pengelompokkan Ikan Padang Lamun dan Terumbu Karang}

\section{Ikan Padang Lamun}

Jenis-jenis ikan yang tertangkap pada ekosistem padang lamun selama 8 kali trip penangkapan sebanyak 16 spesies yaitu Tylosurus crocodiles, Cheilio inermis, Gerres oyena, Choerodon robustus, Parupeneus berbirinus, Sillago sihama, Hermigymnus melapterus, Lethrinus erythropterus, Lutjanus decussates, Lutjanus fulvilamma, Lutjanus bengalensis, Siganus canaliculatus, Siganus chrysospilos, Caranx melampygus, Selar boops dan Cephalopholis microprion. Berdasarkan komposisi jenis ikan tersebut, menunjukkan bahwa daerah padang lamun secara umum berperan secara ekologis bagi berbagai jenis ikan seperti daerah asuhan, tempat berlindung dan tempat mencari makan. Ini ditandai dengan ditemukannya 2 golongan penghuni padang 
lamun yaitu penghuni selama tahap juvenil dan penghuni yang hanya sekali-kali atau sementara mengunjungi padang lamun untuk mencari makan atau tempat berlindung.

Kelompok ikan penghuni selama tahap juvenil yang diperoleh sebanyak 3 jenis yaitu Siganus canaliculatus, Siganus chrysospilos dan Sillago sihama. Sedangkan penghuni yang hanya sekali-kali atau sementara mengunjungi padang lamun untuk mencari makan atau tempat berlindung sebanyak 13 jenis yaitu Tylosurus crocodiles, Cheilio inermis, Gerres oyena, Choerodon robustus, Parupeneus berbirinus, Hermigymnus melapterus, Lethrinus erythropterus, Lutjanus decussates, Lutjanus fulvilamma, Lutjanus bengalensis, Caranx melampygus, Selar boops dan Cephalopholis microprion.

Jenis-jenis ikan penghuni sementara untuk mencari makan atau tempat berlindung umumnya adalah penghuni terumbu karang dan perairan lepas pantai. Hal ini disebabkan karena ekosistem padang lamun berdekatan dengan ekosistem terumbu karang, sehingga hasil tangkapan lebih banyak di dominasi ikan penghuni terumbu karang yang memanfaatkan areal padang lamun sebagai tempat mencari makan dan tempat berlindung dari predator. Tomascik dkk (1997), menyatakan bahwa daerah padang lamun sebagai daerah asuhan dan pembesaran bagi ikan yang sebagian besar bukan penghuni tetap. Lebih lanjut dikatakan Dahuri dkk (2003), bahwa daerah padang lamun sangat berperan sebagai tempat mencari makan dan tempat berlindung. Hutomo dan Martosewejo (1977) dalam Tomascik (1997) menyatakan bahwa ikan penghuni padang lamun hanya selama tahap juvenil yaitu genus Siganidae dan penghuni hanya sekali-kali atau sementara mengunjungi padang lamun untuk mencari makan atau tempat berlindung yaitu umumnya adalah ikan karnivora diantaranya genus Lethrinidae, Caranx dan Scaridae.

Komposisi jenis ikan yang tertangkap merupakan ikan yang memiliki nilai ekonomis karena selalu dikonsumsi oleh masyarakat di sekitar Pulau Sibu. Harga jual ikan bervariasi tergantung ukurannya, hasil pengamatan kisaran harga ikan yang tertangkap Rp. 10.000-15.000/ ekor. Menurut Hutomo (1985) dalam Dahuri (2003), menyatakan bahwa ikan yang tertangkap di padang lamun memiliki nilai ekonomis penting. Komposisi jenis ikan yang hidup di daerah padang lamun Pulau Sibu, bila dibandingkan dengan hasil penelitian Arief (2007) di perairan Maitara Kecamatan Tidore Utara dan Lumaela (2011) di Pulau Donrotu Kecamatan Jailolo Selatan, bahwa komposisi jenis ikan di Pulau Sibu lebih tinggi (13 jenis), dimana di perairan Maitara hanya ditemukan sebanyak 6 jenis dan di Pulau Donrotu sebanyak 5 jenis. yaitu Siganus spinus, Siganus chysospilos, Siganus canaliculatus, Scarus fraenatus, Mulloidichtys flavolineatus.

\section{Ikan Terumbu Karang}

Jenis-jenis ikan yang tertangkap pada ekosistem padang lamun selama 8 kali trip penangkapan sebanyak 16 spesies yaitu Tylosurus 
crocodiles, Cheilio inermis, Gerres oyena, Choerodon robustus, Parupeneus berbirinus, Sillago sihama, Hermigymnus melapterus, Lethrinus erythropterus, Lutjanus decussates, Lutjanus fulvilamma, Lutjanus bengalensis, Siganus canaliculatus, Siganus chrysospilos, Caranx melampygus, Selar boops dan Cephalopholis microprion. Berdasarkan komposisi jenis ikan tersebut, menunjukkan bahwa terumbu karang secara umum berperan secara ekologis bagi berbagai jenis ikan seperti daerah asuhan, tempat berlindung dan tempat mencari makan. Ini ditandai dengan ditemukannya 2 kelompok penghuni terumbu karang yaitu kelompok ikan target dan kelompok ikan mayor (Mayor family).

Kelompok ikan target diperoleh sebanyak 10 jenis yaitu Cheilio inermis, Choerodon robustus, Parupeneus berbirinus, Lethrinus erythropterus, Lutjanus decussates, Lutjanus fulvilamma, Lutjanus bengalensis, Siganus canaliculatus, Siganus chrysospilosdan Cephalopholis microprion. Sedangkan kelompok ikan mayor/lain yaitu Hermigymnus melapterus. Komposisi jenis ikan yang tertangkap umumnya merupakan jenis ikan target yang selalu dimanfaatkan oleh masyarakat. Sebagaimana Allen (2000) menyatakan bahwa ikan yang menjadi target dalam penangkapan yaitu ikan yang memiliki nilai ekonomis dan dapat dikonsumsi oleh nelayan seperti family Serranidae, Lutjanidae, Kyphosidae, Lethrinidae, Acanthuridae, Mulidae, Siganidae, Labridae dan Haemulidae. Semua jenis ikan yang tertangkap tersebut dikonsumsi oleh masyarakat sekitar Pulau Sibu dengan nilai jual bervariasi tergantung ukurannya, hasil pengamatan kisaran harga ikan yang tertangkap Rp. 10.000-15.000/ ekor.

Komposisi jenis ikan terumbu karang yang tertangkap di Pulau Sibu bila dibandingkan hasil penelitian Lumaela (2011) di Pulau Donrotu lebih banyak di Pulau Sibu yaitu 16 jenis sedangkan di Pulau Donrotu sebanyak 14 jenis yaitu Siganus canaliculatus, Siganus spinus, Siganus chysospilos, Scarus fraenatus, Scarus quoyi, Calotomus spinidens, Epinephelus quoyanus, Mulloidichtys flavolineatus, Lutjanus gibbus, Heniochus varius, Chaetodon auriga, Monodactylus argenetus, Pristipomoides auricillia dan Rhinecanthus verrucosus. Sedangkan komposisi jenis ikan pada ekosistem padang lamun sebanyak 5 jenis yaitu Siganus spinus, Siganus chysospilos, Siganus canaliculatus, Scarus fraenatus, Mulloidichtys flavolineatus.

\section{Struktur Komunitas Ikan}

Keseluruhan analisis keanekaragaman jenis, dominasi jenis dan kemerataan jenis (gambar 2). Struktur komunitas ikan yang tertangkap pada ekosistem terumbu karang dan padang lamun. Hasil yang diperoleh untuk ekosistem terumbu karang dengan keanekaragaman jenis $\mathrm{H}^{\prime}=2,57$, dominansi jenis $C=0,09$ dan kemerataan jenis $E=0,93$. Sedangkan ikan yang tertangkap pada ekosistem padang lamun, diperoleh $H^{\prime}=2,39$, dominansi jenis $C=0,11$ dan kemerataan jenis $E=0,93$. Berdasarkan 
hasil analissi tersebut, maka dapt dikatakan bahwa ikan yang tertangkap baik pada eksosistem padang lamun maupun terumbu karang dengan kategori keanekaragaman jenis sedang, tidak ada jenis yang mendominasi serta penyebaran jenis dangat merata.

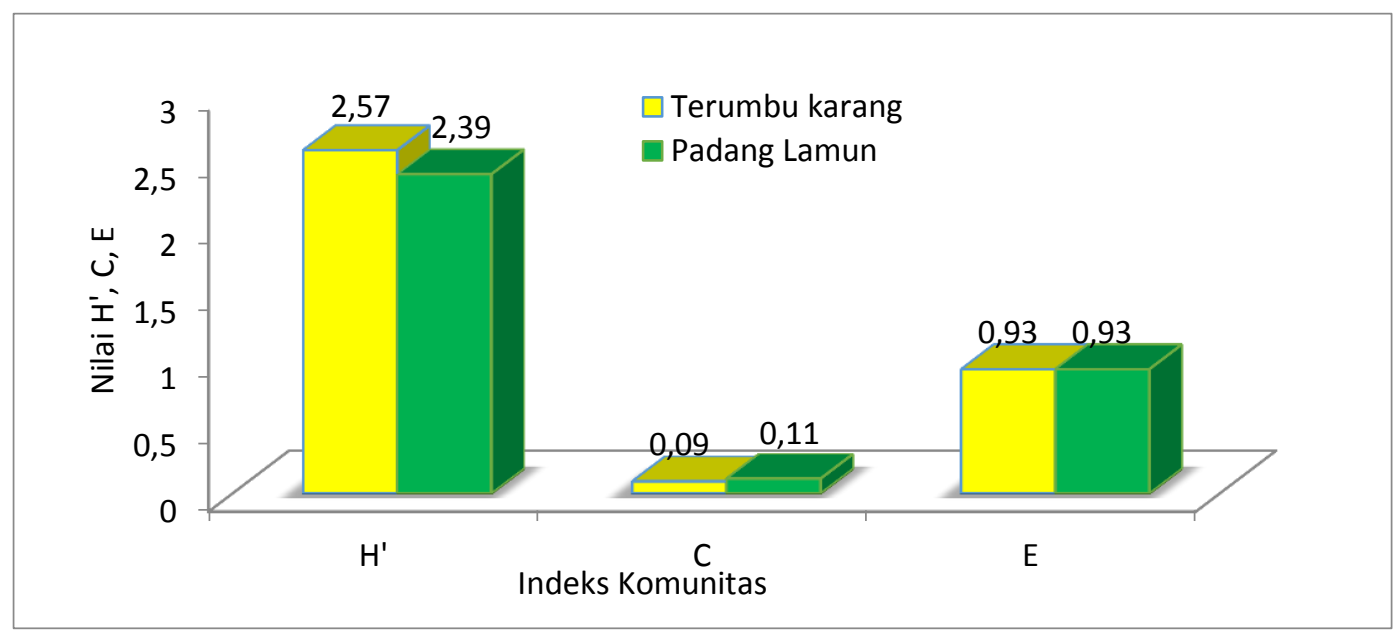

Gambar 2. Keanekaragaman Jenis, Dominasi Jenis dan Kemerataan Jenis Ikan pada Ekosistem Terumbu Karang dan Padang Lamun.

Indeks keanekaragaman jenis adalah ukuran kekayaan komunitas dilihat dari jumlah spesies dalam suatu komunitas, berikut jumlah individu dalam tiap spesies (Ludwig dan Reynolds, 1988). Keanekaragaman jenis yang diperoleh tersebut dipengaruhi oleh jumlah jenis serta jumlah individu yang diperoleh. Selain itu juga dipengaruhi oleh selektivitas alat yang digunakan berupa alat tangkap berupa perangkap/sero yang memiliki ukuran mata jaring yang sangat kecil sehingga ikan yang masuk kedalam sero tersebut tidak bisa keluar. Menurut Soegiarto (1994), bahwa suatu komunitas dikatakan mempunyai keanekaragaman yang tinggi jika komunitas itu disusun oleh banyak spesies, sebaliknya jika komunitas itu disusun oleh sedikit spesies maka keanekaragamannya rendah. Ludwig dan Reynolds (1988), bahwa jika H' > 3, maka keanekaragaman jenis tinggi dan jika $1<\mathrm{H}^{\prime}<3$, maka keanekaragaman sedang dan jika nilai $\mathrm{C}$ mendekati 0 berarti tidak ada spesies yang mendominasi dan apabila nilai C mendekati 1 berarti adanya salah satu spesies yang mendominasi. Lebih lanjut menurut Wibisono (2005), bahwa nilai kemerataan $>0,81$ menunjukkan penyebaran jenis sangat merata.

Nilai dominasi yang didapat dipengaruhi oleh nilai keanekaragaman jenis yang diperoleh tinggi dan sedang. Menurut Odum (1996) bahwa indeks keanekaragaman jenis berbanding terbalik dengan indeks dominasi, yaitu indeks keanekaragaman jenis yang tinggi di suatu tempat, maka pada tempat itu tidak terdapat spesies yang dominan, begitu juga sebaliknya apabila keanekaragaman jenis rendah maka ada jenis yang mendominasi.Kemeratan jenis yang diperoleh, menunjukkan bahwa semua jenis ikan yang tertangkap baik pada ekosistem terumbu karang 
maupun padang lamun memiliki penyebaran sangat merata. Sebagaimana Wibisono (2005), menyatakan bahwa nilai kemerataan $>0,81$ menunjukkan penyebaran jenis sangat merata.

\section{Perbedaan Rata-Rata Hasil Tangkapan Ikan Pada Ekosistem Terumbu Karang dan Padang Lamun}

Uji kenormalan liliefors dari hasil analisis diperoleh nilai untuk hasil tangkapan ikan pada ekosistem terumbu karang $\left(L_{0}=0,1008<L=0,285\right)$, dan hasil tangkapan ikan pada ekosistem padang lamun diperoleh $\left(\mathrm{L}_{0}=\right.$ $0,1172<\mathrm{L}=0,285)$, hal ini menunjukan bahwa hasil tangkapan ikan di kedua ekosistem tersebut berdistribusi normal, atau hipotesa nol di terima. Sudjana (1996) mengatakan bahwa Jika $\mathrm{L}_{0}>\mathrm{L}$, maka $\mathrm{H}_{0}$ ditolak atau $\mathrm{H} 1$ di terima dan $\mathrm{L}_{0}<\mathrm{L}$, maka $\mathrm{H}_{0}$ diterima dan $\mathrm{H}_{1}$ ditolak. Untuk mengetahui perbedaan rata-rata hasil tangkapan ikan antara ekosistem terumbu karang dan padang lamun digunakan pengujian hipotesis beda dua ratarata, uji statistiknya menggunakan distribusi $t$ (Hasan, 1999; Lolombulan, 2004).

Hasil uji t student diperoleh yaitu hipotesis $\mathrm{H}_{1}$ di terima atau hipotesis $\mathrm{H}_{0}$ ditolak, dimana nilai $\mathrm{t}=1,28<t_{(7)}=4,60$, yang artinya bahwa rata-rata hasil tangkapan ikan denganyang dioperasikan pada ekosistem terumbu karang dan ekosistem padang lamun dengan menggunakan alat tangkap jaring insang adalah sama. Hal ini dibuktikan dari hasil tangkapan diantara kedua ekosistem yang tidak jauh berbeda, dimana rata-rata hasil tangkapan ikan pada ekosistem terumbu karang sebanyak 15,25 ekor dan padang lamun sebanyak 12,63 ekor. Ini juga terlihat dari komposisi jenis hasil tangkapan yang tidak jauh berbeda, dimana pada ekosistem terumbu karang sebanyak 16 jenis dan ekosistem padang lamun 13 jenis. Rata-rata hasil tangkapan ikan yang tertangkap pada ekosistem terumbu karang dan padang lamun adalah sama,ini menunjukkan bahwa kedua ekosistem tersebut merupakan habitat dari berbagi jenis ikan yang tertangkap yang menjadikan kedua ekosistem tersebut sebagai daerah asuhan, daerah pembesaran, daerah pemijahan dan terutama daerah mencari makan. Selain itu jarak antara ekosistem terumbu karang dan padang lamun sangat dekat (3 meter). Sehingga ikan-ikan yang hidup di kedua ekosistem saling bermigrasi dalam hal mencari makan. Dibuktikan juga dari hasil tangkapan ikan yang tertangkap di terumbu karang ada sebagian ikan yang hidup di padang lamun begitu juga sebaliknya ikan yang tertangkap di daerah padang lamun ada jenis-jenis ikan yang hidup pada ekosistem terumbu karang.

Komposisi jenis ikan yang tertangkap pada ekosistem padang lamun dari 13 jenis, terdapat 7 jenis ikan terumbu karang yaitu Myripristis burndti, Lutjanus ehrenbergii, Lutjanus decussates, Lutjanus fulvilamma, Monotaxis granduculis, Parachaetodon ocellatus dan Hermigymnus melapterus. Sedangkan dari 16 jenis ikan yang tertangkap pada ekosistem terumbu karang, terdapat 9 jenis ikan yang hidup di daerah 
padang lamun maupun pantai yaitu Tylosurus crocodiles, Cheilio inermis, Gerres oyena, Parupeneus berbirinus, Sillago sihama, Siganus canaliculatus, Siganus chrysospilos, Caranx melampygus dan Selar boops. Ini menunjukkan bahwa kedia ekosistem tersebut saling berinteraksi yaitu berupa interaksi biologi dalam menyedia habitat untuk mencari makan dimana ikan yang hidup di ekositem terumbu karang dapat bermigrasi mencari makan pada ekosistem padang lamun dan sebaliknya. Bengen (2003) menyatakan bahwa mangrove, terumbu karang dan padang lamun (seagrass) merupakan tiga ekosistem penting di pesisir. ketiganya saling berinteraksi dan membentuk suatu kesatuan ekosistem yang erat. Salah satu bentuk interaksi yaitu secara biologi, terjadi interaksi antara ketiga habitat tersebut dalam menyediakan ruang dan media hidup bagi organisme laut. Organisme laut dalam berbagai tingkatan hidupnya bermigrasi dari dan ke masing-masing habitat, tipe migrasinya dapat dikelompokkan antara lain (1) migrasi sementara untuk mencari makan dan (2) migrasi tahapan hidup (larvae, post larva, juvenile, dewasa).

\section{KESIMPULAN}

Komposisi jenis hasil tangkapan pada ekosistem terumbu karang sebanyak 16 spesies dan pada ekosistem padang lamun sebanyak 13 spesies. Keanekaragaman jenis ikan baik pada ekosistem terumbu karang maupun padag lamuntergolong sedang, tidak ada jenis yang mendominasi serta penyebaran jenisnya sangat merata. Rata-rata hasil tangkapan ikan antara ekosistem terumbu karang dan padang lamun adalah sama.

\section{DAFTAR PUSTAKA}

Abubakar, S dan A. Achmad. 2013. Tumbuhan Air(Panduan Pengajaran).LepKhair. Universitas Khairun. Ternate.

Adrim, M. 1993. Pengantar Studi Ekologi Komunitas Ikan Karang dan Metode Pengkajian dalam Kursus Pelatihan Puslitbang Oseanologi. Lembaga IImu Pengetahuan Indonesia. Jakarta.

Arief, F. 2007. Identifikasi Jenis-Jenis Ikan yang Tertangkap di Daerah Padang Lamun (Seagrass) Perairan Maitara Kecamatan Tidore Utara Kota. Skripsi. Jurusan MSP FPIK. Unkhair. Ternate.

Bengen, D.G. 2003. Sinopsis Ekosistem dan Sumberdaya Alam Pesisir dan Laut serta Prinsip Pengelolaannya.Pusat Kajian Sumberdaya Pesisir dan Lautan, Institut Pertanian Bogor. Bogor.

Dahuri, R. 2003. Keanekaragam Hayati Laut. Aset Pembangunan Berkelanjutan Indonesia. PT. Gramedia Pustaka Utama. Jakarta. 
Hasan, M. I. 2002. Pokok-Pokok Materi Statsitik 2 (Statsitik Inferensi). Edisi kedua. Bumi Aksara. Jakarta.

Lolombulan J. H. 2004. Statistik Pada Program Alih Tahun 2004.Program Pascasarjana Universitas Sam Ratulangi. Manado.

Ludwig, E.J and Reynolds. 1988. Statistical Ecology A Primer in Methods and Compting. John Wiley and Sons. New York.

Lumaela, M. M. 2011. Komunitas Ikan pada Ekosistem Terumbu Karang dan Padang Lamun serta Penentuan Ukuran Mata Jaring Insang Dasar (Bottom gillnet) Di Pulau Donrotu Desa Sidangoli Dehe Kecamatan Jailolo Selatan Kabupaten Hamlahera Barat. Skripsi. FPIK Prodi PSP. Unkhair. Ternate.

Norau, S. 2010. Analisis Optimisasi Pemanfaatan Sumberdaya Ikan Lencam (Lethrinus lentjam) Di Kawasan Terumbu Karang Kepulauan Guraici Kabupaten Halmahera Selatan. Tesisi. Sekolah Pascasarjana ITB. Bogor.

Peristiwady, T. 2006. Ikan-Ikan Laut Ekonomis Penting di Indonesia. Petunjuk Identifikasi. Penerbit LIPI. Jakarta.

Rondo, M. 2004. Metodologi Analisis Ekologi Populasi dan Komunitas Biota Perairan. Program Pascasarjana. Unsrat. Manado.

Suhud. 2009. Kajian Komunitas Ikan pada Ekosistem Padang Lamun di Pulau Sali Kecamatan Gane Barat Kabupaten Halmahera Selatan. Skripsi. Jurusan MSP. Unkhair. Ternate.

Tomascik, T., A. J. Mah, A. Nontji dan M.K. Moosa. 1997. The Ecology of the Indonesia Seas. Part Two Periplus Edition (H. K). Ltd Singapore.

Wibisono, M.S. 2005. Pengantar IImu Kelautan. Penerbit PT. Gramedia Widiasarana. Jakarta. 